\title{
Physiological potential of Physalis peruviana $L$. seeds under different temperatures and light wavelengths
}

\section{Potencial fisiológico de sementes de Physalis peruviana L. sob diferentes temperaturas e comprimentos de onda}

\author{
Verônica Pellizzaro ${ }^{1 *}$; Mônica Satie Omura ${ }^{1}$; Felipe Favoretto Furlan ${ }^{1}$; Denis \\ Santiago da Costa $^{2}$; Raissa Marrafon Ponce ${ }^{1}$; Gustavo Henrique Freiria ${ }^{1}$; Helio \\ Fernandes Ibanhes Neto ${ }^{1}$; Lúcia Sadayo Assari Takahashi ${ }^{3}$
}

Resumo

\begin{abstract}
Physalis peruviana L. é uma planta que produz pequenos frutos adocicados de grande importância nutricional e medicinal. Esse vegetal é propagado principalmente através de sementes, as quais necessitam de informações de respostas a temperatura e luz para germinação. Assim, o presente trabalho objetivou avaliar o uso de diferentes temperaturas e comprimentos de ondas de luz sobre o potencial fisiológico de lotes de sementes de P. peruviana. O experimento foi desenvolvido com sementes provenientes das safras $2015 / 15$ e 2016/16. Os tratamentos foram: duas temperaturas de germinação (constante de $25^{\circ} \mathrm{C}$ e alternada de $20 / 30^{\circ} \mathrm{C}$ ), dois lotes de sementes (safra 2015/15 e 2016/16) e quatro formas de exposições à luz durante a germinação (azul, vermelho, branca e escuro). Os dados foram submetidos a análise de componentes principais utilizando a matriz de correlação obtida por meio da média geral padronizada centrada em zero e variância 1 dos parâmetros avaliados para cada tratamento. Os autovalores e autovetores da matriz foram obtidos utilizando o software estatístico SAS University Edition $^{\circledR}$. As variáveis analisadas foram: Teste de germinação realizado no $7^{\circ}$ e $28^{\circ}$ dia considerando a protrusão de raiz, plântulas normais, comprimento de parte aérea, comprimento de raiz e massa de matéria seca total. Foi evidenciado que a germinação de sementes de Physalis peruviana L. deve ser realizada na presença de luz, nas temperaturas constante de $25^{\circ} \mathrm{C}$ ou alternada de $20 / 30^{\circ} \mathrm{C}$. Quando submetidas ao teste no escuro, deve-se utilizar termoperíodo de $20-30{ }^{\circ} \mathrm{C}$ para proporcionar a expressão do máximo potencial fisiológico.
\end{abstract}

Palavras-chave: Fisális. Germinação. Termoperíodo.

\begin{abstract}
Physalis peruviana $L$. is a plant that produces small sweet berries of great nutritional and medicinal importance. This plant is propagated mainly through seeds, which requires information on germination response to temperature and light changes. Thus, the present study aimed to evaluate the use of different temperatures and light wavelengths on the physiological potential of $P$. peruviana seed batches. The experiment was conducted with seeds from plants cultivated in 2015/15 and 2016/16. The treatments
\end{abstract}

\footnotetext{
1 Discentes, Universidade Estadual de Londrina, UEL, Londrina, PR, Brasil. E-mail: veronicapellizzaro@hotmail.com; monica omura@hotmail.com; ffavorettofurlan@gmail.com; raissamp@hotmail.com; gustavo-freiria@hotmail.com; helioibanhes@ hotmail.com

2 Prof., Instituto Federal de Educação, Ciência e Tecnologia de Mato Grosso do Sul, IFMS, Nova Andradina, MS, Brasil. E-mail: denisccauel@gmail.com

3 Prof $^{\mathrm{a}} \mathrm{Dr}^{\mathrm{a}}$, Departamento de Agronomia, Centro de Ciências Agrárias, UEL, Londrina, PR, Brasil. E-mail: sadayo@uel.br Author for correspondence
} 
applied were the following: two germination temperatures (constant temperature of $25^{\circ} \mathrm{C}$ and alternated between $20 / 30{ }^{\circ} \mathrm{C}$ ), two seed batches (2015/15 and 2016/16), and four forms of light exposure during germination (blue, red, white, and dark). The data were analyzed by principal component analysis using the correlation matrix obtained through the standardized mean equal to zero and variance 1 of the parameters evaluated for each treatment. The eigenvalues and eigenvectors of the matrix were obtained using the SAS University Edition ${ }^{\circledR}$ statistical software. The analyzed variables were: Germination test performed on the $7^{\text {th }}$ and $28^{\text {th }}$ day considering root protrusion, normal seedlings, shoot length, root length, and total dry matter mass. The data showed that the seed germination test of Physalis peruviana $L$. should be performed under a constant temperature of $25^{\circ} \mathrm{C}$, in the presence of light (white, blue, or red). When the option is the application of the test in the dark, it is necessary to use a thermoperiod of $20-30{ }^{\circ} \mathrm{C}$ to provide the expression of maximum physiological potential.

Key words: Goldenberry. Germination. Thermal periodicity.

\section{Introduction}

Physalis peruviana L. is a species belonging to the family of Solanaceae, widely recognized for having fruits with high amounts of vitamin C, vitamin A, vitamin B complexes, minerals, tocopherols, and carotenoids (RAMADAN, 2011). In addition to its nutritional importance, in Brazil the fruits are considered exotic, with high added value due to the flavor and the differential marketing of the fruits due to the presence of the calyx (LIMA et al., 2009).

In the process of agricultural production of this species, new plants are produced by means of asexual propagation, by using cuttings or in vitro cultivation, or by sexual multiplication, by using seeds (RUFATO et al., 2008). However, knowledge about its seed physiology is scarce compared to other solanaceous species, as there are no recommendations for germination of $P$. peruviana in the Rules for Seed Testing (BRASIL, 2009).

Temperature and light are two factors that influence the process of germination of the seeds. These parameters can be controlled, to optimize the speed, percentage, and synchronization of the germinative process, which results in reduced production expenses and more vigorous seedlings (NASSIF et al., 1998). Light and temperature requirements differ by species, since each one has its particular requirements in order for germination to occur quickly and uniformly (CARVALHO; NAKAGAWA, 2000).
Temperature variations have the potential to affect the percentage, the uniformity and the speed of germination of several species; and the optimum temperature is the one that permits the most efficient combination of speed and percentage of germination (MARCOS FILHO, 2015). According to the Rules for Seed Testing (BRASIL, 2009), for the species Physalis alkekengi and Physalis pubescens, the recommended temperature for the germination test is between $20-30{ }^{\circ} \mathrm{C}$ in the presence of light; however, most of the studies conducted with Physalis peruviana have been at a constant temperature of $25{ }^{\circ} \mathrm{C}$, according to research by Fernandes et al. (2016), with $\mathrm{X}$ ray tests used for the evaluation of the physiological quality of the seeds of Physalis peruviana at different stages of development, and Souza et al. (2016), with the installation of germination tests in research carried out with seed storage of $P$. peruviana.

As for the light factor, some species have seeds that depend on the presence of light for germination, since germination is triggered by the formation of far-red phytochrome, which is formed by the absorption of light (red light corresponding to $660 \mathrm{~nm}$ ); while others react indifferently to the presence of this factor (MARCOS FILHO, 2015). The phytochrome is a protein present in plant cells, which is associated with plant response to light stimuli. The influence of light on germination and the initial establishment of the plant has been the focus of several studies, leading to greater success in seedling production and an increase in 
the establishment of plants in the initial phase of cultivation (MATOS et al., 2009; BANDEIRA et al., 2011; LOPES et al., 2005).

Bewley et al. (2013) point out that the response of seeds to light during germination is directly related to thermoperiodicity, as such, sensitivity varies by species. Heschel et al. (2007) report that germination depends on both phytochromes and temperature, and that even small changes in temperature have a great effect on the contribution of certain phytochromes to germination. Mondo et al. (2010) observe that different species had specific requirements for the germination of seeds, and that some species need light for twinning to occur.

Considering the above, the present study aimed to evaluate the effects of different temperatures and wavelengths of light on the physiological potential of seed batches of $P$. peruviana.

\section{Material and Methods}

Physalis peruviana L. seeds, represented by two batches from the Londrina State University production field, harvest 2015/15 and 2016/16, were extracted from fruits at full maturation stage $\left(22{ }^{\circ} \mathrm{C}\right)$ and stored under refrigeration $\left(10{ }^{\circ} \mathrm{C}\right)$ in a glass container with a polyethylene lid until the time of analysis. On the day prior to the application of the treatments, the seeds were removed from refrigeration and maintained at a temperature of 20 ${ }^{\circ} \mathrm{C}$ for complete thermal equilibrium.

For the evaluation of seed batch behavior, a principal component analysis was proposed, with four replicates, and the treatments were applied as described in Table 1. The two temperatures studied were proposed based on those most commonly used for other species of Physalis, available in the Rules for Seed Testing, since $P$. peruviana has no recommendation (BRASIL, 2009).

Table 1. Description of treatments such as temperature combinations, photoperiods and wavelengths for seed germination of $P$. peruviana seeds.

\begin{tabular}{ccc}
\hline Wavelength $^{1}$ & Temperature & Lot \\
\hline Blue $-440-485 \mathrm{~nm}$ & Constant $\left(25^{\circ} \mathrm{C}\right)$ & $15 / 15$ \\
Blue $-440-485 \mathrm{~nm}$ & Constant $\left(25^{\circ} \mathrm{C}\right)$ & $16 / 16$ \\
Blue $-440-485 \mathrm{~nm}$ & Alternating $\left(20-30{ }^{\circ} \mathrm{C}\right)$ & $15 / 15$ \\
Blue $-440-485 \mathrm{~nm}$ & Alternating $\left(20-30{ }^{\circ} \mathrm{C}\right)$ & $16 / 16$ \\
Red $-625-740 \mathrm{~nm}$ & Constant $\left(25^{\circ} \mathrm{C}\right)$ & $15 / 15$ \\
Red $-625-740 \mathrm{~nm}$ & Constant $\left(25^{\circ} \mathrm{C}\right)$ & $16 / 16$ \\
Red $-625-740 \mathrm{~nm}$ & Alternating $\left(20-30{ }^{\circ} \mathrm{C}\right)$ & $15 / 15$ \\
Red $-625-740 \mathrm{~nm}$ & Alternating $\left(20-30{ }^{\circ} \mathrm{C}\right)$ & $16 / 16$ \\
White $-370-750 \mathrm{~nm}$ & Constant $\left(25^{\circ} \mathrm{C}\right)$ & $15 / 15$ \\
White $-370-750 \mathrm{~nm}$ & Constant $\left(25^{\circ} \mathrm{C}\right)$ & $16 / 16$ \\
White $-370-750 \mathrm{~nm}$ & Alternating $\left(20-30{ }^{\circ} \mathrm{C}\right)$ & $15 / 15$ \\
White $-370-750 \mathrm{~nm}$ & Alternating $\left(20-30{ }^{\circ} \mathrm{C}\right)$ & $16 / 16$ \\
Dark & Constant $\left(25^{\circ} \mathrm{C}\right)$ & $15 / 15$ \\
Dark & Constant $\left(25^{\circ} \mathrm{C}\right)$ & $16 / 16$ \\
Dark & Alternating $\left(20-30{ }^{\circ} \mathrm{C}\right)$ & $15 / 15$ \\
Dark & Alternating $\left(20-30{ }^{\circ} \mathrm{C}\right)$ & $16 / 16$ \\
\hline
\end{tabular}

${ }^{1}$ Wavelength relative to the visible light obtained by illumination with cold white lamps; ${ }^{2}$ Thermoperiod of $16 \mathrm{~h}$ at $30{ }^{\circ} \mathrm{C}$ and $8 \mathrm{~h}$ at $20^{\circ} \mathrm{C}$. 
Initially, to avoid sensitization of the phytochromes in the seeds, sowing was carried out in an isolated room, which was surrounded by an external light whose internal illumination was coming from a green lamp, to which phytochrome is insensitive. Germination was obtained by equidistant distribution of 50 seeds per replicate, on blotter-type paper $(10.5 \times 10.5 \mathrm{~cm})$, moistened with distilled water in an amount equivalent to 2.5 times the initial mass of the substrate, inside plastic boxes $(11 \times 11 \times 3.5 \mathrm{~cm})$. The plastic boxes (gerbox) were then wrapped in plastic film (cellophane) which allowed four forms of exposure to light (blue, red, white, and dark) and packed in transparent plastic bags to prevent loss of moisture.

The seed samples were taken to BOD-type chambers with either a constant temperature of $25{ }^{\circ} \mathrm{C}$, under a $24 \mathrm{~h}$ light regime, or alternated at 20-30 ${ }^{\circ} \mathrm{C}$, with a light regime of $16 \mathrm{~h}$ at $30^{\circ} \mathrm{C}$ and $8 \mathrm{~h}$ at $20^{\circ} \mathrm{C}$, as recommended for other species of Physalis in Rules for Seed Testing (BRASIL, 2009).

The protrusion of the primary root was evaluated at 7 and 28 days after sowing, and the number of normal seedlings at 28 days after sowing. The normality criterion was adopted, as proposed by the Rules for Seed Testing (BRASIL, 2009), in which seedlings that show potential to continue their development and give rise to normal plants when developed under favorable conditions are considered normal.

In addition, at the end of the germination test (28 days after sowing) the shoot and primary root length were determined by measuring the normal seedling parts, using a ruler graduated in centimeters adapted from Nakagawa (1999). Afterwards the parts were packed in kraft paper bags and kept in a forced circulation oven at $80^{\circ} \mathrm{C}$ for $24 \mathrm{~h}$, and then weighed on a precision scale adapted from Nakagawa (1999). The results were expressed in $\mathrm{mg} /$ seedling.

Principal component analysis was performed, using the correlation matrix obtained by using the standardized overall zero-centered mean and variance 1 of the parameters evaluated for each treatment. This standardization was performed to avoid overestimating or underestimating the significance of a variable studied to the final result, due to differences in the scale of measurement of the parameters (MINGOTI; SILVA, 1997). The eigenvalues and eigenvectors of the matrix were obtained using the SAS statistical software (2000), University Edition ${ }^{\circledR}$. The scores for each new component related to the treatments as well as the graphs were calculated and elaborated using Microsoft Office Excel software ${ }^{\circledR}$.

\section{Results and Discussion}

According to the overall means presented in Table 2, differences in the seed behavior of $P$. peruviana under the proposed treatments can be observed. According to the principal components analysis, the parameters evaluated resulted in linear combinations giving rise to six new components, of which the first two were responsible for $81.52 \%$ of the total variation (Table 3 ). The first component, $\mathrm{CP}_{1}$, presented the highest retention of data variability (58.82\%), followed by the second component, $\mathrm{CP}_{2}$ $(22.70 \%)$, while the other components summed only retained a total of $18.48 \%$ of the variability. According to Jolliffe (2002), retention of the variability of the summed components must surpass $80 \%$, for one to be able to interpret the results referring to the principal component analysis, in this case only two.

Analyzing the first component, represented by the linear equation $\mathrm{CP}_{1}=0.475 \times($ Standardized PRP $)+$ $0.473 \times($ standardized FC $)+0.472 \times($ standardized NS) $-0.160 \times($ standardized APL $)+0.396 \times$ (standardized RL) $+0.382 \times($ standardized TDM), it was observed that the primary root protrusion (PRP), first count (FC), and normal seed (NS), had the highest contributions and were considered the main characteristics in the construction of the new variable $(0.475,0.473$ and 0.472 , respectively). Thus, this component represented the germination 
potential of the seeds of $P$. peruviana, and the higher the positive value of each treatment for this component, the higher the seedling performance. On the other hand, the second component, $\mathrm{CP}_{2}=0.336$ $\times($ standardized PRP $)+0.143 \times($ standardized FC $)+$ $0.366 \times($ standardized NS $)+0.670 \times($ standardized APL) $-0.407 \times($ standardized RL) $-0.344 \times$ (standardized TDM), had the highest contributions (greater than 0.40 in module) provided by aerial part length (APL) and root length (RL) with 0.670 and -0.407 , respectively, and high positive values for this new component were related to better development of the seedlings during the test (Figure 1A).

Table 2. Mean of results for each treatment which were obtained for normal seedlings 28 days after sowing (NS), protrusion of the primary root 7 days after sowing (FC), primary root protrusion at 28 days after sowing (PRP), shoot length (APL), root length (RL) and total dry mass (TDM) for P. peruviana.

\begin{tabular}{ccccccccc}
\hline Wavelength & Temperature & Lot & NS (\%) & FC $(\%)$ & PRP $(\%)$ & APL $(\mathrm{mm})$ & RL $(\mathrm{cm})$ & TDM $(\mathrm{mg})$ \\
\hline Blue & Constant $\left(25^{\circ} \mathrm{C}\right)$ & $15 / 15$ & 92 & 42 & 95 & 30.1 & 1.57 & 4 \\
Blue & Constant $\left(25^{\circ} \mathrm{C}\right)$ & $16 / 16$ & 27 & 38 & 46 & 17.8 & 2.56 & 4.25 \\
Blue & Alternating $\left(20-30{ }^{\circ} \mathrm{C}\right)$ & $15 / 15$ & 84 & 96 & 94 & 16.1 & 3.33 & 5 \\
Blue & Alternating $\left(20-30^{\circ} \mathrm{C}\right)$ & $16 / 16$ & 39 & 24 & 47 & 11.2 & 2.27 & 2.25 \\
Red ${ }^{2}$ & Constant $\left(25^{\circ} \mathrm{C}\right)$ & $15 / 15$ & 92 & 66 & 99 & 31.8 & 2.84 & 4.35 \\
Red & Constant $\left(25^{\circ} \mathrm{C}\right)$ & $16 / 16$ & 56 & 34 & 64 & 27.3 & 2.42 & 4.25 \\
Red & Alternating $\left(20-30^{\circ} \mathrm{C}\right)$ & $15 / 15$ & 90 & 96 & 99 & 13.1 & 3.33 & 4.25 \\
Red & Alternating $\left(20-30^{\circ} \mathrm{C}\right)$ & $16 / 16$ & 25 & 35 & 38 & 5.5 & 1.62 & 1.45 \\
White & Constant $\left(25^{\circ} \mathrm{C}\right)$ & $15 / 15$ & 100 & 58 & 100 & 31.0 & 2.83 & 4.9 \\
White & Constant $\left(25^{\circ} \mathrm{C}\right)$ & $16 / 16$ & 45 & 26 & 50 & 20.1 & 3.54 & 5.85 \\
White & Alternating $\left(20-30^{\circ} \mathrm{C}\right)$ & $15 / 15$ & 96 & 99 & 98 & 26.5 & 2.92 & 4.2 \\
White & Alternating $\left(20-30^{\circ} \mathrm{C}\right)$ & $16 / 16$ & 38 & 44 & 40 & 4.5 & 2.23 & 5.85 \\
Dark & Constant $\left(25^{\circ} \mathrm{C}\right)$ & $15 / 15$ & 8 & 3 & 8 & 52.7 & 1.52 & 1.5 \\
Dark & Constant $\left(25^{\circ} \mathrm{C}\right)$ & $16 / 16$ & 14 & 0 & 16 & 39.0 & 0.55 & 2.25 \\
Dark & Alternating $\left(20-30^{\circ} \mathrm{C}\right)$ & $15 / 15$ & 91 & 95 & 95 & 35.2 & 1.78 & 3.45 \\
Dark & Alternating $\left(20-30^{\circ} \mathrm{C}\right)$ & $16 / 16$ & 74 & 42 & 91 & 31.9 & 103 & 2.85 \\
\hline
\end{tabular}

${ }^{1}$ Blue wavelength - 440-485 nm; ${ }^{2}$ Red wavelength - 625-740 nm; ${ }^{3}$ Visible wavelength - 370-750 nm.

The results obtained for each wavelength at 25 ${ }^{\circ} \mathrm{C}$ (Figure 1B) led to the formation of three groups: the first group, with positive values for $\mathrm{CP}_{1}$ and $\mathrm{CP}_{2}$ (1st quadrant) was composed of the seeds in lot L015/15 that were germinated in the presence of white, red, and blue light. As previously described, $\mathrm{CP}_{1}$ is related to the germination potential of the seeds, i.e., the higher the positive value for $\mathrm{CP}_{1}$ the higher the seed performance in the presence of light (white, red or blue) at $25{ }^{\circ} \mathrm{C}$ for this batch (Figure 1B), results which are confirmed by Table 2 .
The second group presented negative values for $\mathrm{CP}_{1}$ and positive for $\mathrm{CP}_{2}\left(2^{\text {nd }}\right.$ quadrant $)$, and consisted of seeds that were germinated in the dark at $25{ }^{\circ} \mathrm{C}$, with similar results for both $\mathrm{L} 015 / 15$ and L016/16 (Figure 1B). In this group, a low percentage of germination and seedlings were observed (Table $2)$. The third group was formed by the seeds of the lot L016/16, with negative values for $\mathrm{CP}_{2}\left(3^{\text {rd }}\right.$ and $4^{\text {th }}$ quadrants), germinated with wavelengths of white, red and blue light (Figure 1B). The values for $\mathrm{CP}_{1}$ were intermediate, indicating an intermediate germinative potential (Table 2). 
Thus, it was noted that at $25{ }^{\circ} \mathrm{C}$, light was a determinant factor for seed germination of $P$. peruviana, since in the dark, germination occurred at very low rates for both batches studied. This may be related to seed dormancy and the need for light to germinate, because when the seeds were exposed to blue, red or white light, germination rates were higher. According to Ozaslan et al. (2016), the germination of Physalis angulata and Physalis philadelphica is slightly affected by photoperiods, which suggests that the seeds are slightly photoblastic, indicating that the same behavior occurs in P. peruviana.

Figure 1 Results of principal component analysis. A - Eigenvectors for $\mathrm{CP}_{1}$ and $\mathrm{CP}_{2}$; $\mathrm{B}$ - Scores for wavelengths at 25 ${ }^{\circ} \mathrm{C}$; C - Scores for wavelengths at $20-30^{\circ} \mathrm{C}$.
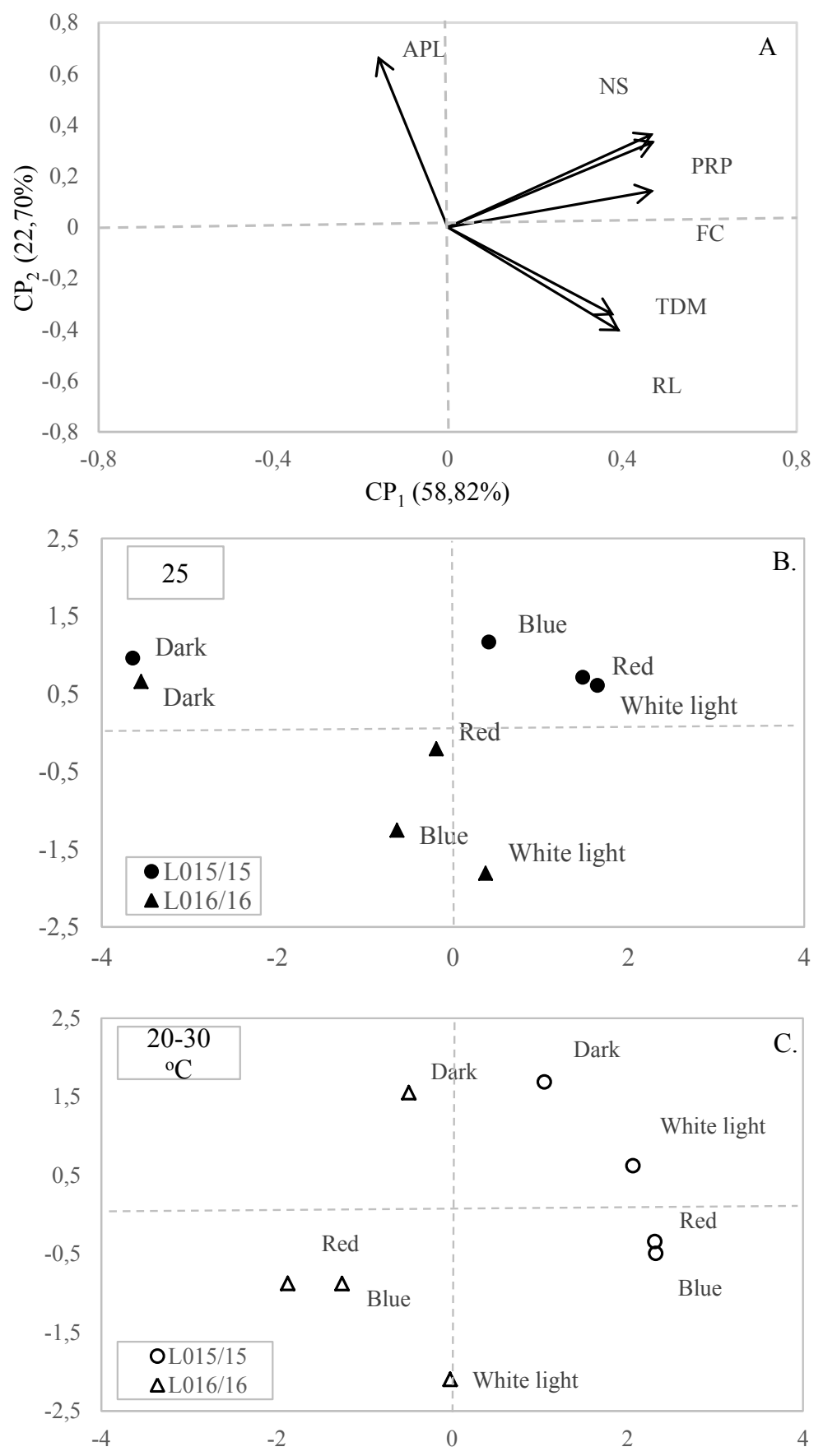
Light is commonly needed for germination in some species, as verified by Yamashita et al. (2011) in a study with Conyza seeds, in which light was a determining factor for germination. In an experiment conducted by Silva et al. (2016) with Jatropha curcas seeds, it was verified that in the presence of light, there is a homogenization of the germinative parameters in all batches analyzed, which does not happen in the dark. Under controlled conditions, Cardoso et al. (2015) verified that a temperature of $20^{\circ} \mathrm{C}$, the presence of constant light and a filter paper substrate led to the most uniform germination of $P$. peruviana seeds.

Table 3. Results obtained from the correlation matrix of the results of primary root protrusion (PRP), first count (FC), normal seedlings (NS), shoot length (APL) root length (RL), and total dry mass (TDM) to P. peruviana.

\begin{tabular}{|c|c|c|c|c|}
\hline \multirow[b]{2}{*}{ Components } & \multicolumn{4}{|c|}{ 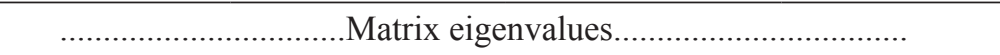 } \\
\hline & Eigenvalue & Difference & Proportion & Cumulative \\
\hline $\mathrm{CP}_{1}$ & 3.5295 & 2.1676 & $58.82 \%$ & $58.82 \%$ \\
\hline $\mathrm{CP}_{2}$ & 1.3618 & 0.7292 & $22.70 \%$ & $81.52 \%$ \\
\hline $\mathrm{CP}_{3}$ & 0.6326 & 0.3222 & $10.54 \%$ & $92.07 \%$ \\
\hline $\mathrm{CP}_{4}$ & 0.3104 & 0.1564 & $5.17 \%$ & $97.24 \%$ \\
\hline $\mathrm{CP}_{5}$ & 0.1540 & 0.1423 & $2.57 \%$ & $99.81 \%$ \\
\hline $\mathrm{CP}_{6}$ & 0.0116 & - & $0.19 \%$ & $100.00 \%$ \\
\hline
\end{tabular}

The first component efficiently separated the seeds from lot L015/15 of L016/16, by analyzing the results obtained under alternating temperatures of $20-30{ }^{\circ} \mathrm{C}$ (Figure 1C), forming two distinct groups (1st and 4th quadrant for L015/15; $3^{\text {rd }}$ and $4^{\text {th }}$ quadrant for $\left.L 016 / 16\right)$. However, there was no separation for the seeds that were germinated in the dark, contrary to the result obtained at 25 ${ }^{\circ} \mathrm{C}$ (Figure 1B). It was thus observed that the thermoperiodicity provided by alternating $20-30{ }^{\circ} \mathrm{C}$ may be a solution for overcoming seed dormancy in P. peruviana (Table 2). The influence of the far-red phytochrome on the temperature required for overcoming dormancy may be associated with the effects of temperature on processes mediated by the phytochrome (PONS, 2000). According to Heschel et al. (2007), small changes in temperature have a large effect on the contribution of particular phytochromes to germination.

According to Takaki (2001), seeds of $P$. peruviana germinate both in the presence of light and in the dark, and can be classified as neutral photoblastic. However, this categorization cannot be considered definitive, since other factors, such as humidity and temperature, can alter their photoblastic characteristics, a fact confirmed by the results obtained for germination in the dark under thermoperiodicity (Table 2 and Figure 1C).

Regarding the batches, although different values were observed between the two harvests due to the lower physiological quality of L016/16, the response was similar for the temperature and light conditions, indicating that their behavior is independent of the initial seed quality. Thus, it was verified that for the germination physiology of $P$. peruviana seeds, the light and temperature factors strongly interact with each other, and are able to influence principally the number of normal seedlings germinated and seedling length.

\section{Conclusions}

The seed germination test of Physalis peruviana L. must be performed under a constant temperature of $25{ }^{\circ} \mathrm{C}$, in the presence of light (white, blue or red). When the test is performed in the dark, the 
thermoperiod of $20-30{ }^{\circ} \mathrm{C}$ should be used to provide the expression of maximum physiological potential.

\section{Acknowledgments}

The authors are grateful to the National Research Council (CNPq) and the Coordinating Body for the Improvement of Higher Level Personnel (CAPES) for financial support and fellowships.

\section{References}

BANDEIRA, A. S.; SANTOS, J. L.; SANTOS, D. L. Desenvolvimento inicial e acúmulo da biomassa de mudas de pinhão manso em diferentes condições de luminosidade. In: CONGRESSO BRASILEIRO DE AGROECOLOGIA, 7., 2011, Fortaleza. Anais... Fortaleza: Cadernos de Agroecologia, 2011. p. 1-6.

BEWLEY, J. D.; BRADFORD, K.; HILHORST, H.; NONOGAKI, H. Seeds: physiology of development, germination and dormancy. $3^{\text {rd }}$. New York: Springer, 2013. $392 \mathrm{p}$.

BRASIL. Ministério da Agricultura, Pecuária e Abastecimento. Regras para análise de sementes. Brasília: Secretaria de Defesa Agropecuária, 2009. 395 p.

CARDOSO, E. B.; PINTO, L. V. A.; RAPOSO, P. C.; ROCHA, L.C. D. Caracterização dos frutos, curva de embebição das sementes e efeito da temperatura e substratos na germinacão de Physalis peruviana. In: CONGRESSO NACIONAL DE MEIO AMBIENTE DE POÇOS DE CALDAS, 7., 2015, Poços de Caldas. Anais... Poços de Caldas: 2015. p. 1-7.

CARVALHO, N. M.; NAKAGAWA, J. Sementes: ciência, tecnologia e produção. 4. ed. Jaboticabal: Funep, 2000. 590 p.

FERNANDES, J. S.; SILVA, D. F. da; SANTOS, H. O. dos; VON PINHO, É. V. D. R. Teste de raios X na avaliação da qualidade de sementes de frutos de fisális em diferentes estádios de desenvolvimento. Revista de Ciências Agroveterinárias, v. 15, n. 2, p. 165-168, 2016. DOI: $10.5965 / 223811711522016165$

HESCHEL, M. S.; SELBY, J.; BUTLER, C.; WHITELAM, G. C.; SHARROCK, R. A.; DONOHUE, $\mathrm{K}$. A new role for phytochromes in temperature dependent germination. New Phytologist, v. 174, n. 4, p. 735-741, 2007. DOI: $10.1111 /$ j.1469-8137.2007.02044.x

JOLLIFFE, I. T. Principal component analysis. $2^{\text {nd }}$ ed. New York: Springer-Verlag, 2002. 487 p.
LIMA, C. S. M.; SEVERO, J.; MANICA-BERTO, R.; SILVA, J. A.; RUFATO, L; RUFATO, A. R. Características físico-químicas de physalis em diferentes colorações do cálice e sistemas de condução. Revista Brasileira de Fruticultura, v. 31, n. 4, p. 1061-1068, 2009. DOI: 10.1590/S0100-29452009000400020

LOPES, J. C.; CAPUCHO, M. T.; MARTINS FILHO, S.; REPOSSI, P. A. Influência de temperatura, substrato e luz na germinação de sementes de bertalha. Revista Brasileira de Sementes, v. 27, n. 2, p. 18-24, 2005. DOI: 10.1590/S0101-31222005000200004

MARCOS FILHO, J. Fisiologia de sementes de plantas cultivadas. Piracicaba: FEALQ, 2015. 495 p.

MATOS, F. S.; MOREIRA, C. V.; MISSIO, R. F.; DIAS, L. A. dos S. Caracterização fisiológica de mudas de Jatropha curcas L. produzidas em diferentes níveis de irradiância. Revista Colombiana de Ciências Horticolas, v. 3, n. 1, p. 126-134, 2009. DOI: 10.17584/ rcch.2009v3i1.1204

MINGOTI, S. A.; SILVA, A. F da. Um exemplo de aplicação de técnicas de estatística multivariada na construção de índices de preços. Nova Economia, v. 7, n. 2, p. 203-212, 2013.

MONDO, V. H. V.; CARVALHO, S. J. P. D.; DIAS, A. C. R.; MARCOS FILHO, J. Efeitos da luz e temperatura na germinação de sementes de quatro espécies de plantas daninhas do gênero Digitaria. Revista Brasileira de Sementes, v. 32, n. 1, p. 131-137, 2010. DOI: 10.1590/ S0101-31222010000100015

NAKAGAWA, J. Testes de vigor baseados no desempenho das plântulas. In: KRZYZANOWSKI, F. C.; VIEIRA, R. D.; FRANÇA NETO, J. de B. Vigor de sementes: conceitos e testes. Londrina: Abrates, 1999. p. 20-31.

NASSIF, S., VIEIRA, I., FERNADES, G. Germinação de sementes: fatores externos (ambientais) que influenciam a germinação. Piracicaba: Informativo Sementes IPEF, 2004.

OZASLAN, C.; FAROOQ, S.; ONEN, H.; BUKUN, B.; OZCAN, S.; GUNAL, H. Invasion potential of two tropical physalis species in arid and semi-arid climates: Effect of water-salinity stress and soil types on growth and fecundity. PloS one, v. 11, n. 10, p. e0164369, 2016. DOI: $10.17265 / 2161-6264 / 2018.06 .002$

PONS, T. L. Seed responses to light. In: FENNER, M. Seeds: the ecology of regeneration in plant communities. 2. ed. Wallingford: CABI Publishing, 2000. p. 237-260.

RAMADAN, M. F. Bioactive phytochemicals, nutritional value, and functional properties of cape gooseberry (Physalis peruviana): an overview. Food Research 
International, v. 44, n. 7, p. 1830-1836, 2011. DOI: 10.1016/j.foodres.2010.12.042

RUFATO, L.; RUFATO, A. R.; SCHLEMPER, C.; LIMA, C. S. M.; KRETZSCHMAR, A. A. Aspectos técnicos da cultura da Physalis. Lages: CAV/ UDESC; Pelotas: UFpel, 2008. 100 p.

STATISTICAL ANALYSIS SYSTEM INSTITUTE SAS Statistical Software V8, SAS Institute Inc., Cary, NC, USA, 2000.

SILVA, F. J. D.; HISATUGO, E. Y.; SOUZA, J. P. D. Efeito da luz na germinação e desenvolvimento de plântulas de pinhão-manso (Jatropha curcas L.) de distintas procedências. Hoehnea, v. 43, n. 2, p. 195-202, 2016. DOI: $10.1590 / 2236-8906-80 / 2015$
SOUZA, C. L. de.; SOUZA, M. O. D.; OLIVEIRA, R. S.; PELACANI, C. R. Physalis peruviana seed storage. Revista Brasileira de Engenharia Agrícola e Ambiental, v. 20 , n. 3, p. 263-268, 2016. DOI:10.1590/1807-1929/ agriambi.v20n3p263-268

TAKAKI, M. New proposal of classification of seeds based on forms of phytochrome instead of photoblastism. Revista Brasileira de Fisiologia Vegetal, v. 13, n. 1, p. 104-108, 2001. DOI: 0.1590/S0103-31312001000100011

YAMASHITA, O. M.; GUIMARAES, S. C.; CAVENAGHI, A. L. Germinação das sementes de Conyza canadensis e Conyza bonariensis em função da qualidade de luz. Planta Daninha, Viçosa, v. 29, n. 4, p. 737-743, 2011. DOI: $10.1590 / \mathrm{S} 0100-83582011000400003$ 
